\title{
Multi-criteria Analysis for Energy Independence from Renewable Energy Sources Case Study Zakynthos Island, Greece
}

\author{
Ioannis Vardopoulos
}

\begin{abstract}
The current research deals with renewable energy sources for the energy independence of Zakynthos Island in Greece. In order to define the most efficient renewable energy source, a multi-criteria analysis was used. The main criteria that were applied are the three pillars of sustainability, namely environment, society and economy. The aforementioned criteria were also subject to the DPSIR model of indicators, while a range of economic, environmental, social and technical sub-criteria were applied. The results, with regard to the delimitations set for the scope of the current research, indicate that the solar energy source systems (photovoltaics) are proved to be a more suitable alternative over a geothermal power station.
\end{abstract}

Index Terms-Renewable energy sources, photovoltaics, geothermal, multi-criteria analysis, sustainability indicators.

\section{INTRODUCTION}

Nowadays, energy demand is considered an important world problem with serious consequences on the environment, the economy and therefore societal development. Recent utilization of renewable energy sources aims both towards oil independence, financially speaking, and protecting the environment from the unsustainable human use. Renewable energy sources will, at some point soon, overcome the environmental, social, economic, technical and institutional obstacles which they sometimes face. The environmental impact of renewable energy sources use has more or less been identified, including the extensive use of land and natural resources, the alteration of the landscape, the visual impact, etc.. The intricate renewable energy source problems make the selection between the alternatives offered a multidimensional problem [1]. The purpose of this work is to define, document and finally select the most efficient, appropriate and effective renewable energy source, from an environmental, social and economic point of view, for the energy independence of an island. For this to be satisfied, we refer to Greece, and particularly Zakynthos Island, as a case study. The selection of this particular Island was made in an attempt to use as a case study a place that combines certain characteristics, as mentioned below.

Energy plans and designs intend to determine the optimal combination of energy sources in order to satisfy a given energy demand, and so the responsible EU bodies have

Manuscript received December 5, 2016; revised February 6, 2017.

Ioannis Vardopoulos is with Harokopio University, Greece (e-mail: ivardopoulos@post.com). already since 1996, shown the way towards renewable energy sources issuing the Green Paper. Following that, the context for the impairment of adverse effects and risks was set along with the alignment of the Member States in the new order through the White Paper, focusing on four parameters: a) institutionalized incentives and facilities for those who choose to utilize renewable energy sources; b) open-up markets to import renewable energy sources; c) promote the use of renewable energy especially for public transportation, public lighting and heating and d) incentivize/motivate energy proofing of buildings and infrastructure [2]. Thus, EU willing to apply policies towards "green" direction and follow previously mentioned contexts, have set out some (non-legislative) objectives, such as the sustainable management of energy with low greenhouse gas emissions against global warming, the creation of a network for the reliable and low level energy supply losses, the operation of 'free market' and competitiveness aiming at affordable prices for the final recipient, etc. [2].

According to the European Directives, such as the 2009/28/EC, some, non-binding, quantitative objectives have been set towards 2020, which, among others, mainly include a $20 \%$ reduction in greenhouse gas emissions -from 1990 levels-, measures towards $20 \%$ energy coming from renewable sources and finally $20 \%$ improvement in energy efficiency [2]. Accordingly, EU, recognizing that these objectives are not enough for achieving an overall sustainable balance of the already strained environment, has set even higher objectives towards 2030. These include, among others $20 \%$ greenhouse gas emissions reduction (40\% overall), $7 \%$ further improvement in energy efficiency using renewable energy sources (20\% total), $10 \%$ in energy efficiency improvement (30\% total), and to reach a point where each country will be able to deliver $15 \%$ of the total produced energy (thus including the $40 \%$ energy coming from renewable energy sources) to other countries within or outside Europe. Respectively, even more ambitious are the objectives set towards 2050, taking also into account the intensity of climate change, aiming to $50 \%$ greenhouse gas emissions reduction [2]. For the successful application of the above-mentioned guidelines, a number of legally binding and a number of other non-legally binding guidelines (documents) have been drawn-up and adopted by the Member States. Some of them are: a) the 2001/77/EC Directive regarding the national objectives for each Member State towards 2020; b) the 2003/30/EC Directive concerning the biofuels promotion towards oil replacement (at least for public transportation); c) the 2004/8/EC Directive concerning the encouragement towards multifaceted energy production using conventional 
and renewable energy sources, etc. [2].

Of the first items of legislation in Greece were the enactment of laws 2773/1999 and 3468/2006, which both set some national objectives, such as achieving the energy production of $20 \%$ of the domestic consumption out of renewable energy sources until 2010 and 30\% until 2020, institutionalizing the licensing process, authorizing hybrid energy production solutions on islands, setting cost incentives for the use of renewable sources of electricity, and more [3]. The Law 3851/2010 regarding the further development of renewable energy sources to address climate change, along with similar provisions under the supervision of the Greek Ministry of Environment and Energy, incorporate 2009/28/EC Directive into the national legislation and together with the earlier 3734/2009 Law set the following objectives towards 2020: a) $40 \%$ of renewable energy in the gross electricity consumption; b) $20 \%$ share of consumption from renewable energy sources for heating and cooling and c) $10 \%$ share of consumption from renewable energy sources in transport sector. It also includes issues related to simplifying licensing procedures for renewable energy systems installation and the creation of a renewable energy agency for the exploitation of natural resources in Greece, targeted to renewable energy production and the development of green growth strategies and plans, etc. [3].

\section{CASE Study AnALYSIS — ZAKYNTHOS Island}

Zakynthos Island was chosen because it is internationally known due to its natural and cultural characteristics some of which include protected areas of great importance, rich and unique natural resources. This island combines a certain geology and climate that could potentially accommodate different kind of renewables, a certain economy (tourism sector) which creates fluctuation in energy demand, while the earthquake activity is constantly present, which sets certain difficulties in installations and structures.

The area of the island reaches $410 \mathrm{~km} 2$, approximately 40 $\mathrm{km}$ long and $19 \mathrm{~km}$ wide, while the coastline is about $122 \mathrm{~km}$ long and the population is 40,564 inhabitants according to the latest census [4]. Zakynthos area is a large island, 11th in the size rank of the Greek islands and the 3rd largest in the Ionian Sea. Half of the total area of the island is farmland and $10 \%$ pastures, while, despite the frequent and extensive fires, $35 \%$ of the island's area is covered by forests [4]. The road network is nearly $95 \mathrm{~km}$ (major roads), there are two main ports which connect the island with central Greece and Italy, as well as many other smaller harbors and marinas. A national airport operates, hosting flights of medium-sized aircraft. The cultural heritage of the island is rich with a number of archaeological sites and monuments. According to recent studies, it appears that in Zakynthos approximately 100 areas (of a total $60 \mathrm{~km}^{2}$ surface) are suitable for the installation or renewable energy systems [5]. The extent and the location of these areas is the outcome of the implementation of certain criteria in combination with the buffering of the conflicting areas (ex. environmental restriction -set by law-, infrastructure, housing, rivers, road networks, industry, cultural sites, etc.).

The climate of the mountainous part of Zakynthos is
Mediterranean, mild, without extreme temperatures [6]. Conditions of still air appear $36 \%$ of the time of a year and maximum wind speed can reach up to 8 Beaufort. The prevalent winds are northern and southern. Winds are stronger from November to February. The temperature rarely drops below $1^{\circ}$ or $2^{\circ}$ Celsius degrees. Humidity in November reaches $76 \%$, whereas in July reaches up to $59 \%$. According to rainfall stations in Zakynthos, rain reaches an average height of $943 \mathrm{~mm}$. Monthly meteorological data of the year 2014 are presented in Table I.

The Independent Power Transmission Operator reports, indicate that in order to cover Zakynthos energy needs, underwater power transmission lines connect the island with the neighboring island of Kefalonia and with the national hinterland system on the side of the Ilia region (power lines $150 \mathrm{kV}$ ). The island is traversed with a $150 \mathrm{kV}$ single circuit transmission network, which joins the underwater power transmission lines on both sides, using a substation located in the city centre [4].

An electric power station with the capacity of $27 \mathrm{MW}$ operates on the island, also located in the city centre. The energy needs of the island resulting from the consumption as recorded by the Hellenic Statistical Authority [4] are presented in Table II.

Zakynthos owns two very important inhabitants of rare marine species protected by international conventions and domestic Law's. The first habitat is associated with the reproduction of the sea turtle Caretta Caretta, located in Laganas Bay. The second habitat concerns the reproduction of the Mediterranean Mock Seal Monachus Monachus and is situated in the western and northern coastal cliffs of the island. Both areas are a pole of attraction for tourists.

The National Marine Park of Zakynthos, a $1350 \mathrm{~km}^{2}$ area, was established by Law in 1999, the first of its kind in Greece and an example for other regions in Greece that require integrated management of the environment. In Zakynthos, there have been recorded three wildlife sanctuaries, an Area of Conservation (SAC), and a zone protected by the Special Protected Areas (SPA) Law (Greek Official Gazette 906/D/22.12.1999).

Furthermore, two more special areas of conservation of about $650 \mathrm{~km}^{2}$ and two more special protection areas of about $2150 \mathrm{~km}^{2}$ have been identified. Finally, aligning with the European Directive 92/43/EC regarding the conservation of nature habitats and wild flora and fauna, Zakynthos state has legislated networks of protected areas of Natura 2000 project (National Marine Park of Zakynthos).

Therefore, it is our understanding that all three pillars of sustainability, namely environment, society and economy must be thoroughly studied in order to determine, which renewable energy systems are the most efficient for use in this island.

\section{The Alternatives}

Renewable energy sources are in general considered those sources that use natural resources which can be replaced in human time scale, such as sunlight, wind, rain, tides, waves and geothermal energy [7]. Renewable energy sources often provide energy on four key sectors, the electricity production 
services, cooling and heating systems, the transport sector and the rural services [8]-[10]. A brief description of the alternatives offered in this case study follow.

TABLE I: METEOROLOGICAL MONTHLY DATA, 2014 (WORLD METEOROLOGICAL ORGANIZATION)

\begin{tabular}{lcccccc}
\hline \hline & $\begin{array}{c}\text { Atmospheric } \\
\text { pressure } \\
(\mathrm{hPa})\end{array}$ & $\begin{array}{c}\text { Average } \\
\text { Temp } \\
\left(\mathrm{C}^{\circ}\right)\end{array}$ & $\begin{array}{c}\text { Average } \\
\text { Humidity } \\
(\%)\end{array}$ & $\begin{array}{c}\text { Average } \\
\text { Rainfall } \\
(\mathrm{mm})\end{array}$ & $\begin{array}{c}\text { Average } \\
\text { Wind } \\
\text { Speed } \\
(\mathrm{m} / \mathrm{s})\end{array}$ & $\begin{array}{c}\text { Average } \\
\text { Wind } \\
\text { Direction }\end{array}$ \\
\hline Jan & 1016.9 & 11.3 & 74 & 150 & 2.2 & se \\
Feb & 1015.1 & 11.5 & 73 & 113 & 2.4 & se \\
Mar & 1014.8 & 12.9 & 73 & 90 & 2.2 & se \\
Apr & 1013.5 & 15.5 & 72 & 51 & 1.9 & se \\
May & 1014.0 & 19.8 & 68 & 17 & 1.8 & se \\
Jun & 1013.5 & 24.1 & 63 & 7 & 1.8 & nw \\
Jul & 1012.6 & 26.7 & 59 & 5 & 2.0 & nw \\
Aug & 1012.8 & 26.6 & 61 & 9 & 1.9 & nw \\
Sep & 1015.5 & 23.8 & 67 & 25 & 1.8 & se \\
Oct & 1017.0 & 19.6 & 72 & 147 & 2.1 & se \\
Nov & 1017.1 & 15.8 & 76 & 159 & 2.0 & se \\
Dec & 1016.5 & 12.8 & 75 & 170 & 2.2 & se \\
Year & 1014.9 & 18.4 & 69 & 943 & 2.0 & se \\
\hline \hline
\end{tabular}

TABLE II: ELECTRIC ENERGY CONSUMPTION IN GREECE (TOTAL) AND IN ZAKYNTHOS BY CATEGORY OF USE: 2012, IN THOUSAND KWH

\begin{tabular}{|c|c|c|c|c|}
\hline & Total & $\begin{array}{c}\text { Domestic } \\
\text { Use }\end{array}$ & Commercial Use & $\begin{array}{c}\text { Industrial } \\
\text { Use }\end{array}$ \\
\hline $\begin{array}{l}\text { Greece } \\
\text { (Total) }\end{array}$ & 51.168 .377 & 18.454 .589 & 14.782 .312 & 12.202 .237 \\
\hline \multirow[t]{2}{*}{ Zakynthos } & 183.659 & 66.377 & 93.645 & 3.553 \\
\hline & & $\begin{array}{c}\text { Agricultural } \\
\text { Use }\end{array}$ & $\begin{array}{c}\text { Public and Municipal } \\
\text { Authorities }\end{array}$ & $\begin{array}{c}\text { Street } \\
\text { Lighting }\end{array}$ \\
\hline $\begin{array}{l}\text { Greece } \\
\text { (Total) }\end{array}$ & & 2.727 .453 & 2.118 .450 & 883.335 \\
\hline Zakynthos & & 654 & 9.296 & 10.134 \\
\hline
\end{tabular}

Solar Energy; Solar energy is energy that is transferred to the earth from the sun. This is primordial, mild and renewable energy source. The energy of the sun comes from the nuclear fusion reactions to its mass, by converting hydrogen into helium at a rate of 4 billion tons per second. The earth's surface receives directly and indirectly radiation, which in Europe stands for $50 \%$ of the total [11]. Photovoltaic elements directly convert solar energy into electricity. Photovoltaic systems are very flexible and can cover both low and great electricity needs. The obstacles for spreading the photovoltaic systems use is mainly located in a) their relatively high cost $(3.2-4.5 € / \mathrm{kWp}), \mathrm{b})$ the fact that the produced energy(/electricity) is significantly more expensive that the one produced using other renewable energy sources, and c) the huge land exploitation -at least for large power systems- [12].

Geothermal Energy; Geothermal energy is a part of the earth's heat that is stored in the form of hot water or steam in favorable geological conditions. Is limited to the first 3 kilometers from the earth's surface and can be relatively easily been exploited. It is relatively mild, alternative and may be able to cover a significant part of the energy needs [13]. Impact of geothermal source mainly concern a) air pollution which occurs primarily from geothermal systems of high enthalpy, b) the water and thermal pollution from the discharge of geothermal water containing dissolved salts from which heat is extracted, c) the risk for (minor) seismic activity, d) the leaks that occur mainly in the early stages of exploitation and e) the noise. It is known that the geothermal energy has many advantages compared to the solar energy systems [14]. These advantages include: a) not affected by weather conditions, b) it is considered the energy of base load c) is energy of constant flow with low capacity factor (over $90 \%$ in many cases) d) requires less land surface and has less ecological impact. The total installed capacity of geothermal systems, however, is much less than the solar ones [15].

\section{Methodology}

This study attempts to address the energy demand problem of Zakynthos Island. We attempt to find which renewable energy system, applicable in the island's special characteristics would potentially cover the energy needs. For the aim of the current research, two renewable energy source alternatives are examined; Geothermal and Solar Energy Systems. The selection of these particular systems was based on the energy prices per MWh, as currently presented in the Independent Power Transmission Operator in Greece. The methodology implemented is a multi-criteria decision analysis. Following the DPSIR model, indicators for all three pillars of sustainability were developed, along with criteria and sub-criteria. The criteria are subject to weight evaluation (wi) using Saaty's method of pairwise comparison, and the sub-criteria are subject to weight evaluation (wj) using a criterion weight evaluation scale, within the framework of the multi-criteria decision making method of Analytical Hierarchy Process, which provides the ability to control the consistency in the determination of criterion weight [16]. For the scope of this paper, the evaluation was subject to the author's point of view. Sub-criteria are developed aiming the maximum contribution of each renewable energy source in the energy mix and follow the below requirements:

- Compliance with the environmental and ecological constraints, as expressed from the Islands characteristics.

- Compatibility with the current economic, legislative and political conditions.

- Compliance with the technical and technological circumstances of the area concerned and the technical specifications of the proposed alternatives of renewable energy sources.

\section{MUlTi-CRITERIA ANALYSIS AND SUSTAINABILITY INDICATORS}

Indicators are computational sets helpful for simplifying, quantifying and transmitting information [17]. In other words, an indicators system for environment and sustainability looks forward to counterbalancing the proven perpetual need for evaluation and comparison of each alternative to the other. Thus, it is a platform for recording trends concerning the environment [18].

Indicators present the existing status of an area by quantifying the available selected data in measurable terms. Sustainability Indicators could determine the level of development of a region; the current development, the expected and their differences [19]. Indicators are based on the relation between the environment and human, namely the economic and social development, causing Pressures, and therefore Impacts on ecosystems, natural resources (seen as raw materials) and human health, which could effect a social 
Response leading back to Driving forces, or States, or even back to Responses (DPSIR model) [20]. The sustainability indicators which are developed for the scope of the current research are a set of two factors for each one of the three sustainability pillars and are presented in Table III.

TABLE III: ENVIRONMENTAL SUSTAINABILITY INDICATORS (1[US/KWH], KENNY, ET AL., 2010, 2[CO 2 EQUIVALENT G/KWH], 3[KM²/TWH], 4[\%], EVAN, 2009, 5MAJER, ET AL, 2008)

\begin{tabular}{|c|c|c|c|}
\hline & & Photovoltaic & Geothermal \\
\hline & Indicator & & \\
\hline \multirow[t]{2}{*}{ Environment } & $\begin{array}{l}\text { Avoided greenhouse } \\
\text { gas emissions }\end{array}$ & $90^{2}$ & $170^{2}$ \\
\hline & Land Use & $28-64^{3}$ & $18-74^{3}$ \\
\hline \multirow[t]{2}{*}{ Economy } & $\begin{array}{l}\text { Initial Investment } \\
\text { Cost }\end{array}$ & $\$ 0.24^{1}$ & $\$ 0.07^{1}$ \\
\hline & Profitability & $4-22^{4}$ & $10-20^{4}$ \\
\hline \multirow{5}{*}{ Society } & Social Impact & ${ }^{5}$ Toxins: & ${ }^{5}$ Seismic \\
\hline & social Impact & Minor & Activity: Minor \\
\hline & & ${ }^{5}$ Visual: & ${ }^{5}$ Odors: Minor \\
\hline & Social Acceptance & Minor & Noise: Minor \\
\hline & & & Pollution: Minor \\
\hline
\end{tabular}

The number of alternatives or possible solutions requires the application of a decision support method [21]. Data on economic variables, energy efficiency or environmental impact are currently affected by uncertainty [22]. Hence, the importance of multi-criteria analysis arises, to address this high level of complexity and uncertainty [23], given that, multi-criteria analysis can handle numerous data, variables and alternatives. Thus a valuable assistance in decision making is offered, for each case study, following the evaluation and even the under-evaluation of each criterion, sub criterion and/or indicator separately [24]. Of course, this method does not replace the decision makers (actors), but rather supports them in all procedure stages, providing useful information [25].

The identification and selection of criteria and sub-criteria, aimed to include all possible parameters set for studying the potential alternatives, in an attempt to build a representative structure of specific characteristics and to avoid duplicates and overlaps. Thus, twenty four total sub-criteria have been developed, which are respectively classified into three criteria groups, in line with the scope of the current research.

In line with the methodology followed for the scope of the current research and in accordance with the multi-criteria decision analysis steps, in order to compare the alternatives, it is necessary to assess and evaluate the weight of each sub criterion with regard to the characteristics and the degree of influence it holds in this case study. For this reason, a weight evaluation scale is developed and implemented (Table IV).

\begin{tabular}{cl} 
TABLE IV: CRITERION WEIGHT EVALUATION SCALE \\
\cline { 2 - 3 } 1 & Zero \\
2 & Weak \\
3 & Moderate \\
4 & Moderate Plus \\
5 & Strong \\
6 & Strong Plus \\
7 & Very Strong \\
8 & Very, Very Strong \\
9 & Extreme \\
\hline \hline
\end{tabular}

We use the software MakeItRational ${ }^{1}$ to address this

\footnotetext{
${ }^{1}$ The software we used is the free online trial version
}

multi-criteria decision analysis case. The software is a decision making tool based on the Analytical Hierarchy Process (AHP) aiming to help decision makers to conclude to a rational choice. For the sustainability criteria, we used a pairwise comparison, while for the sub-criteria we used weight evaluation, subject to the author's point of view, as expressed in Table V-Table VII.

TABLE V: ENVIRONMENTAL CRITERION WEIGHT EVALUATION

\begin{tabular}{|c|c|c|c|}
\hline & Environmental Criterion & Photovoltaic's & Geothermal \\
\hline $\begin{array}{l}\text { Sub } \\
\text { Cr } 1\end{array}$ & $\mathrm{CO} 2$ Emissions Avoided & 6 & 4 \\
\hline $\begin{array}{l}\text { Sub } \\
\text { Cr } 2\end{array}$ & $\begin{array}{l}\text { Waste Production During } \\
\text { Construction and Operation }\end{array}$ & 6 & 6 \\
\hline $\begin{array}{l}\text { Sub } \\
\text { Cr } 3\end{array}$ & Ecological Impact & 5 & 5 \\
\hline $\begin{array}{l}\mathrm{Sub} \\
\mathrm{Cr} 4\end{array}$ & LCA, Recyclability & 9 & 7 \\
\hline $\begin{array}{l}\text { Sub } \\
\text { Cr } 5\end{array}$ & Required Amount of Land & 4 & 9 \\
\hline $\begin{array}{l}\text { Sub } \\
\text { Cr } 6\end{array}$ & $\begin{array}{l}\text { Environmental Impacts in Case } \\
\text { of Failure }\end{array}$ & 9 & 5 \\
\hline $\begin{array}{l}\text { Sub } \\
\text { Cr } 7\end{array}$ & $\begin{array}{l}\text { Requirements in Anti-Pollution } \\
\text { Measures }\end{array}$ & 5 & 6 \\
\hline $\begin{array}{l}\text { Sub } \\
\text { Cr } 8\end{array}$ & Adaptability to Local Condition & 9 & 5 \\
\hline
\end{tabular}

TABLE VI: ECONOMIC CRITERION WEIGHT EVALUATION

\begin{tabular}{|c|c|c|c|}
\hline & Economic Criterion & Photovoltaics & Geothermal \\
\hline $\begin{array}{l}\text { Sub } \\
\mathrm{Cr} 1\end{array}$ & $\begin{array}{l}\text { Investment, Operational and } \\
\text { Maintenance Costs }\end{array}$ & 8 & 4 \\
\hline $\begin{array}{l}\mathrm{Sub} \\
\mathrm{Cr} 2\end{array}$ & Savings in Conventional Fuels & 8 & 6 \\
\hline $\begin{array}{l}\text { Sub } \\
\text { Cr } 3\end{array}$ & Economic Sustainability & 7 & 9 \\
\hline $\begin{array}{l}\mathrm{Sub} \\
\mathrm{Cr} 4\end{array}$ & Technological Maturity & 8 & 8 \\
\hline $\begin{array}{l}\text { Sub } \\
\text { Cr } 5\end{array}$ & Safety of Supply & 7 & 9 \\
\hline $\begin{array}{l}\text { Sub } \\
\text { Cr } 6\end{array}$ & Seasonal Dependency & 5 & 9 \\
\hline $\begin{array}{l}\text { Sub } \\
\text { Cr } 7\end{array}$ & Profit (net) & 8 & 6 \\
\hline $\begin{array}{l}\text { Sub } \\
\mathrm{Cr} 8\end{array}$ & Employment & 7 & 5 \\
\hline
\end{tabular}

TABLE VII: SOCIAL CRITERION WEIGHT EVALUATION

\begin{tabular}{|c|c|c|c|}
\hline & Social Criterion & Photovoltaics & Geothermal \\
\hline Sub & Contribution to Local & 8 & 7 \\
\hline Cr 1 & Development and Prosperity & & \\
\hline $\begin{array}{l}\text { Sub } \\
\text { Cr } 2\end{array}$ & $\begin{array}{l}\text { Social Acceptance and } \\
\text { Sustainability of Environmental } \\
\text { Impacts }\end{array}$ & 5 & 8 \\
\hline $\begin{array}{l}\mathrm{Sub} \\
\mathrm{Cr} 3\end{array}$ & Human Health Benefits & 8 & 9 \\
\hline $\begin{array}{l}\mathrm{Sub} \\
\mathrm{Cr} 4\end{array}$ & $\begin{array}{l}\text { Required Amount of Land (Visual } \\
\text { Impact-Noise) }\end{array}$ & 7 & 7 \\
\hline $\begin{array}{l}\text { Sub } \\
\text { Cr } 5\end{array}$ & Operating Hours & 9 & 5 \\
\hline $\begin{array}{l}\text { Sub } \\
\text { Cr } 6\end{array}$ & Implementation Time & 9 & 6 \\
\hline $\begin{array}{l}\text { Sub } \\
\mathrm{Cr} 7\end{array}$ & $\begin{array}{l}\text { Compliance with the Existing } \\
\text { Framework }\end{array}$ & 7 & 9 \\
\hline $\begin{array}{l}\mathrm{Sub} \\
\mathrm{Cr} 8\end{array}$ & $\begin{array}{l}\text { Social Consequences in Case of } \\
\text { Failure }\end{array}$ & 9 & 7 \\
\hline
\end{tabular}

\section{RESULTS}

With regard to the delimitations set for the scope of the current paper, results obtained, aiming at improving the quality of decisions through clear and reasonable test results, indicate that the installation of photovoltaic systems is 
slightly a more efficient alternative. The weight evaluation of the three basic criteria is presented in the form of a pie chart (Fig. 1) while the final ranking of the alternatives is given in the form of a bar chart (Fig. 2) which lists the renewable energy systems under evaluation (axis-y) in conjunction with the overall alternative utility of each renewable energy system (axis-x). Total utility represents the total score that occupies each alternative with respect to criteria and sub-criteria satisfaction. The alternative with the highest total utility is considered the optimal one, thus in this case photovoltaics $(50.59 \%$ total score) over the geothermal (49.41\% total score).

Furthermore, from the final ranking of the alternatives, we observe that the social criterion is of greater total utility for the renewable energy system that does not better accomplish the sub-criteria evaluations; geothermal energy systems, contrary to the final outcome, thus a more detailed breakdown in each sustainability criterion and sub-criteria is necessary.
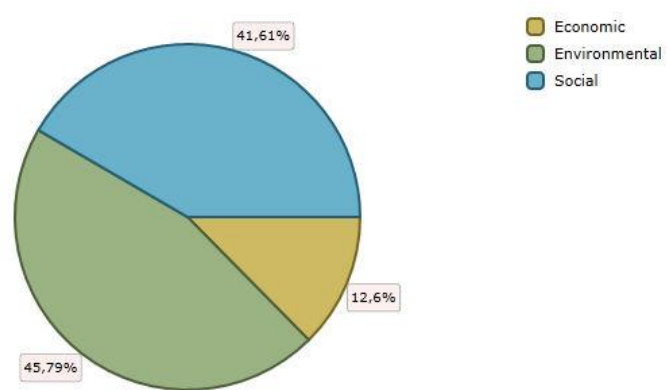

Fig. 1. Evaluation in context of: Photovoltaics vs geothermal.

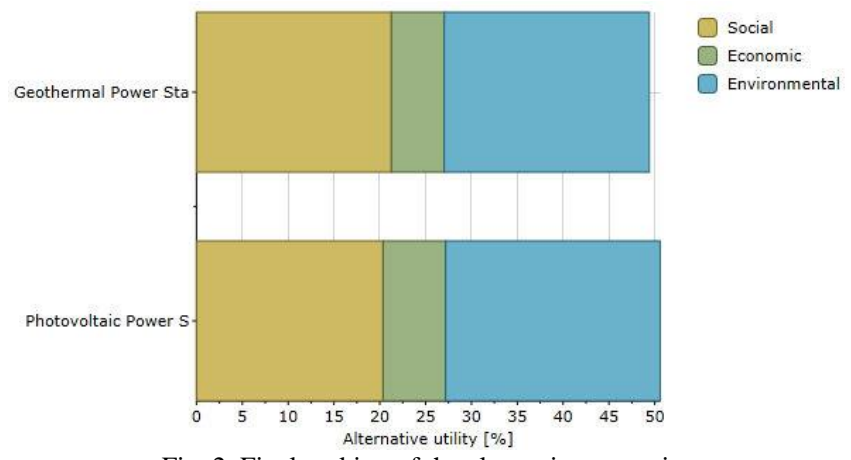

Fig. 2. Final ranking of the alternative scenarios.

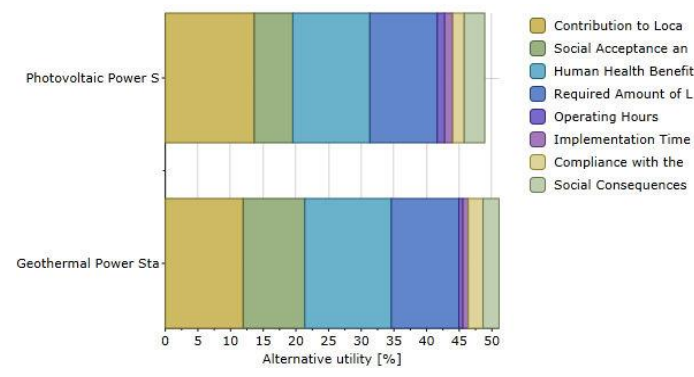

Fig. 3. Final ranking of renewable energy systems in the social criterion

A notable predominance of geothermal energy systems over photovoltaic systems is noticed in the social criterion (Fig. 3). Also noteworthy, is the fact that geothermal energy systems have high satisfaction rate of the social acceptance and sustainability of environmental impacts sub criterion, along with the contribution to local development and prosperity sub criterion, whereas the rest sub-criteria range at almost the same levels. When we examine the criterion representing the cost it is clear that photovoltaic systems better satisfy all sub-criteria with an exception in the seasonal dependency (Fig. 4). Results on the environmental criterion slightly counterbalance in favor of the photovoltaic systems. Extreme difference in sub criterion satisfaction is noted in the required amount of land in favor of geothermal systems and in $\mathrm{CO} 2$ emissions avoided in favor of photovoltaic's (Fig. 5).

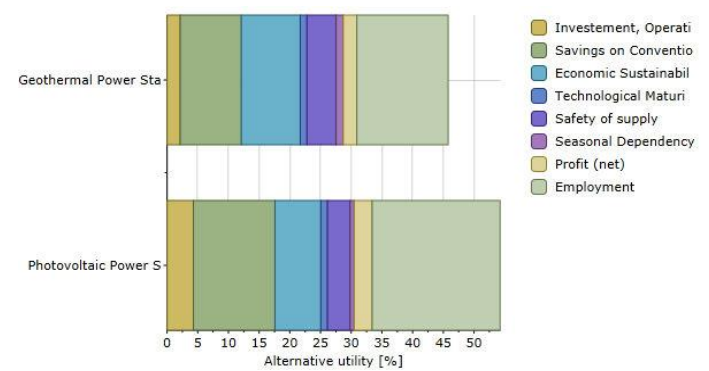

Fig. 4. Final ranking of renewable energy systems in the economic criterion.

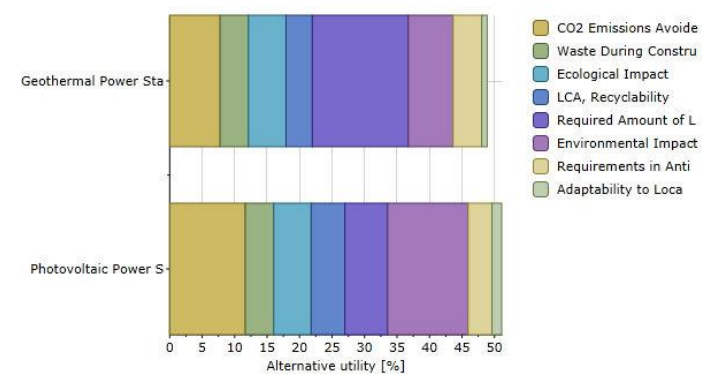

Fig. 5. Final ranking of renewable energy systems in the environmental criterion.

\section{CONCLUSION}

Choosing the most appropriate alternative for the energy independence of Zakynthos Island is a complicated process considering the number of criteria that should be taken into account. As demonstrated, a multi-criteria decision analysis can clearly help in this direction. The application, in the current study, of such analysis, has returned encouraging results, but also pointed out all those parameters that need to be further examined.

Without a doubt, in order to propose the installation of photovoltaic systems as a feasible alternative to cover the island's energy needs, further research, actions, application and plans are required. Apart from the extensive research and studies on alternative scenarios, with regard to technology, function, installation, etc., considerations for a) upgrading and maintaining the existing energy transmission networks are essential, b) limitations and incentives for building's energy proofing should be imposed, and c) additional solutions utilizing renewable energy systems at a localized level (or activities, ex. agriculture), are certainly recommended in order to achieve full energy independence of the island through a 'combined approach'.

Future work includes examining the same way, all available renewable energy system alternatives, along with several combinations (hybrid energy systems). Furthermore, in order to address conclusively this multidimensional issue, a gradual removal of all the delimitations set for the scope of the current paper, is necessary, with regard to the sub criterion weight evaluation, where it is advised to consider 
using extensive qualitative and quantitative survey data.

\section{ACKNOWLEDGMENT}

The author acknowledges that this study is a record of bonafide work done under the valued support of Professor Helen Theodoropoulou.

The author is grateful to Dr. Zoi I. Konstantinou for serving as critical reader of the draft of this research and providing valuable insights for improvement.

Any errors or omission remain the responsibility of the author.

\section{REFERENCES}

[1] T. Tsoutsos, M. Drandaki, N. Frantzeskaki, E. Iosifidis, and I. Kiosses, "Sustainable energy planning by using multi-criteria analysis application in the island of crete," Energy Policy, vol. 37, no. 5, pp. 1587-1600, 2009.

[2] European Commission. (2016). [Online]. Available: http://ec.europa.eu/

[3] Greek Ministry of Environment and Energy. (2016). [Online] Available: http://www.ypeka.gr/

[4] Hellenic Statistical Authority. (2016). [Online]. Available: http://www.statistics.gr/

[5] M. Giannakopoulos, "Application of multi-criteria decision making and spatial analysis to renewable energy development in GIS environment: The case of onshore wind farm in Zakynthos," $\mathrm{PhD}$, National Technical University of Athens, 2015.

[6] A. Kalimeris, D. Founda, C. Giannakopoulos, and F. Pierros, "Long-term precipitation variability in the Ionian Islands, Greece (Central Mediterranean): Climatic signal analysis and future projections," Theoretical and Applied Climatology, vol. 109, no. 1-2, pp. 51-72, 2011.

[7] M. Sanz-Bobi, Use, Operation and Maintenance of Renewable Energy Systems, 1st ed. Springer, 2016.

[8] O. Ellabban, H. Abu-Rub, and F. Blaabjerg, "Renewable energy resources: Current status, future prospects and their enabling technology," Renewable and Sustainable Energy Reviews, vol. 39, pp. 748-764, 2014.

[9] G. Papaefthymiou and K. Dragoon, "Towards 100\% renewable energy systems: Uncapping power system flexibility," Energy Policy, vol. 92 , pp. 69-82, 2016.

[10] B. Sørensen, Renewable Energy, 1st ed. Amsterdam: Elsevier Academic Press, 2004.

[11] J. Wang, J. O'Donnell, and A. Brandt, "Potential solar energy use in the global petroleum sector," Energy, 2016.

[12] D. Diakoulaki and F. Karangelis, "Multi-criteria decision analysis and cost-benefit analysis of alternative scenarios for the power generation sector in Greece," Renewable and Sustainable Energy Reviews, vol. 11, no. 4, pp. 716-727, 2007.
[13] A. Gando, D. Dwyer, R. McKeown, and C. Zhang, "Partial radiogenic heat model for Earth revealed by geoneutrino measurements," Nature Publishing Group, pp. 647-651, 2011.

[14] K. Li, H. Bian, C. Liu, D. Zhang, and Y. Yang, "Comparison of geothermal with solar and wind power generation systems," Renewable and Sustainable Energy Reviews, vol. 42, pp. 1464-1474, 2015.

[15] S. Pohekar and M. Ramachandran, "Application of multi-criteria decision making to sustainable energy planning - A review," Renewable and Sustainable Energy Reviews, vol. 8, no. 4, pp. 365-381, 2004.

[16] J. Cristobal, Multi Criteria Analysis in the Renewable Energy Industry, 1st ed. Springer London Ltd, 2014.

[17] P. Girardin, C. Bockstaller, and H. Werf, "Indicators: Tools to Evaluate the Environmental Impacts of Farming Systems," Journal of Sustainable Agriculture, vol. 13, no. 4, pp. 5-21, 1999.

[18] E. Loken, "Use of multicriteria decision analysis methods for energy planning problems," Renewable and Sustainable Energy Reviews, vol. 11, no. 7, pp. 1584-1595, 2007

[19] K. Robert, T. Parris, and A. Leiserowitz, "What is Sustainable Development? Goals, Indicators, Values, and Practice," Environment: Science and Policy for Sustainable Development, vol. 47, no. 3, pp. 8-21, 2005.

[20] K. Tscherning, K. Helming, B. Krippner, S. Sieber, and S. Paloma, "Does research applying the DPSIR framework support decision making?, Land Use Policy, vol. 29, no. 1, pp. 102-110, 2012.

[21] D. Niemeijer, "Developing indicators for environmental policy: Data-driven and theory-driven approaches examined by example," Environmental Science \& Policy, vol. 5, no. 2, pp. 91-103, 2002.

[22] M. Howlett and J. Cuenca, "The use of indicators in environmental policy appraisal: lessons from the design and evolution of water security policy measures," Journal of Environmental Policy \& Planning, pp. 1-15, 2016.

[23] C. Macharis, J. Bulckaen, and I. Keseru, "The multi-actor multi-criteria analysis in action for sustainable urban mobility decisions: the case of Leuven," International Journal of Multicriteria Decision Making, vol. 6, no. 3, p. 211, 2016.

[24] E. Triantaphyllou, Multi-criteria Decision Making Methods, 1st ed. Kluwer Acad. Publ., 2000.

[25] J. Figueira, S. Greco, and M. Ehrogott, "Multiple criteria decision analysis: State of the art surveys," International Series in Operation Research \& Management Science, 2005.

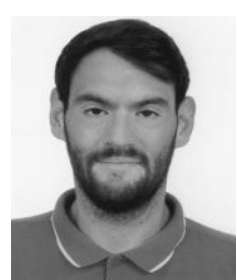

Ioannis Vardopoulos was born in Athens, Greece in 1987. He received his bachelor degree in civil engineering from the Technological Educational Institute of Patras in Greece in 2011. In July 2016, he received his master's degree in environmental conservation and management from the Open University of Cyprus. Currently, he studies sustainable development in a postgraduate program of the Harokopio University of Athens. He has been practicing engineering since 2011 in various residential and commercial projects, and has his own practice in Athens. 